\title{
Speciation analysis of iodine and bromine at picogram-per-gram levels in polar ice
}

\section{Andrea Spolaor, Paul Vallelonga, Jacopo Gabrieli, Natalie Kehrwald, Clara}

Turetta, Giulio Cozzi, Luisa Poto, John M. C. Plane, et al.

Analytical and Bioanalytical Chemistry

ISSN 1618-2642

Volume 405

Combined 2-3

Anal Bioanal Chem (2013) 405:647-654 DOI 10.1007/s00216-012-5806-0

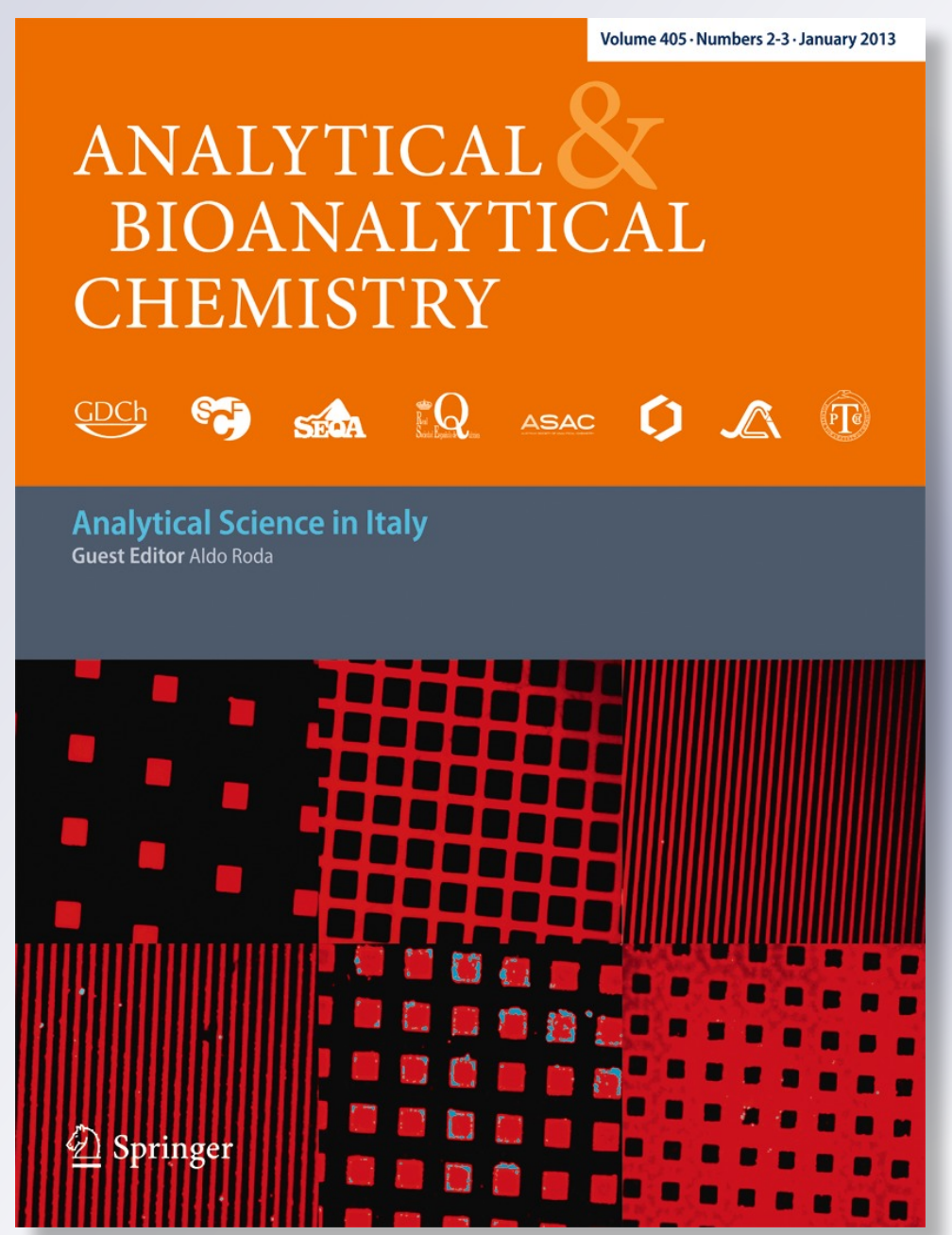

望 Springer 
Your article is protected by copyright and all rights are held exclusively by SpringerVerlag. This e-offprint is for personal use only and shall not be self-archived in electronic repositories. If you wish to self-archive your work, please use the accepted author's version for posting to your own website or your institution's repository. You may further deposit the accepted author's version on a funder's repository at a funder's request, provided it is not made publicly available until 12 months after publication. 


\title{
Speciation analysis of iodine and bromine at picogram-per-gram levels in polar ice
}

\author{
Andrea Spolaor • Paul Vallelonga • Jacopo Gabrieli • \\ Natalie Kehrwald • Clara Turetta • Giulio Cozzi • \\ Luisa Poto • John M. C. Plane • C. Boutron • \\ Carlo Barbante
}

Received: 17 December 2011 / Revised: 28 January 2012 / Accepted: 28 January 2012 /Published online: 17 February 2012

(C) Springer-Verlag 2012

\begin{abstract}
Iodine and bromine species participate in key atmospheric reactions including the formation of cloud condensation nuclei and ozone depletion. We present a novel method coupling a high-performance liquid chromatography with ion chromatography and inductively coupled plasma mass spectrometry, which allows the determination of iodine (I) and bromine (Br) species $\left(\mathrm{IO}_{3}^{-}, \mathrm{I}^{-}, \mathrm{Br}^{-}, \mathrm{BrO}_{3}{ }^{-}\right)$at the picogram-per-gram levels presents in Antarctic ice. Chromatographic separation was achieved using an IONPAC $^{\circledR}$ AS16 Analytical Column with $\mathrm{NaOH}$ as eluent. Detection limits for I and $\mathrm{Br}$ species were 5 to $9 \mathrm{pg} \mathrm{g}^{-1}$ with an uncertainty of less than $2.5 \%$ for all considered species. Inorganic iodine and bromine species have been determined in Antarctic ice core samples, with concentrations close to
\end{abstract}

Published in the special issue Analytical Science in Italy with guest editor Aldo Roda.

\section{A. Spolaor}

Department of Earth Science, University of Siena,

Via del Laterino 8,

53100 Siena, Italy

\author{
A. Spolaor · J. Gabrieli $\cdot$ N. Kehrwald $\cdot$ C. Turetta $\cdot$ G. Cozzi $\cdot$ \\ C. Barbante \\ Institute for the Dynamics of Environmental Processes - CNR, \\ University of Venice, \\ Dorsoduro 2137, \\ 30123 Venice, Italy \\ P. Vallelonga \\ Centre for Ice and Climate, Niels Bohr Institute, \\ Juliane Maries Vej 30, \\ 2100 Copenhagen, Denmark

\section{Poto $\cdot$ C. Barbante} \\ Department of Environmental Sciences, Informatics and Statistics, \\ University Ca' Foscari of Venice, \\ Dorsoduro 2137, \\ 30123 Venice, Italy
}

the detection limits for iodine species, and approximately $150 \mathrm{pg} \mathrm{g}^{-1}$ for $\mathrm{Br}^{-}$. Although iodate $\left(\mathrm{IO}_{3}{ }^{-}\right)$is the most abundant iodine species in the atmosphere, only the much rarer iodide $\left(\mathrm{I}^{-}\right)$species was present in Antarctic Holocene ice. Bromine was found to be present in Antarctic ice as $\mathrm{Br}^{-}$.

Keywords Iodine $\cdot$ Bromine $\cdot$ Speciation $\cdot$ Ice cores .

Antarctica

\section{Introduction}

The atmospheric chemistry of iodine (I) and bromine (Br) are receiving increasing attention due to their importance in

J. M. C. Plane

School of Chemistry, University of Leeds,

Leeds LS2 9JT, UK

\section{Boutron}

Laboratoire de Glaciologie et Géophysique de l'Environnement, UMR UJF/CNRS 5183,

54, rue Molière, Domaine Universitaire, B.P. 96, 38402 Saint Martin d' Hères, France

\section{Barbante $(\bowtie)$}

Accademia Nazionale dei Lincei, Centro B. Segre,

via della Lungara 10 ,

00196 Rome, Italy

e-mail: barbante@unive.it 
insolation-related atmospheric processes [1,2], formation of cloud condensation nuclei [3], and the chemical depletion of ozone [4]. Furthermore, observations are in discrepancy with model outputs which suggest that iodate should be the main I species in atmospheric depositions [5, 6].

Iodine is a trace element present in the Earth's atmosphere at relatively low concentrations in the range of 1$100 \mathrm{ng} \mathrm{m}^{-3}$ [7]. Iodine is principally emitted into the atmosphere in the organic form by oceanic primary production [8], although sea spray aerosol emissions are negligible due to the low concentration of I in seawater ( 400 to $500 \mathrm{nM}$ [9]). In the ocean, $\mathrm{I}$ is mostly present in the $\mathrm{IO}_{3}{ }^{-}$form [10], even though significant quantities of $\mathrm{I}^{-}$have been detected, most likely as a product of biological cycling [11].

Several chemical forms of I exist in aerosols including the inorganic forms $\mathrm{I}^{-}$and $\mathrm{IO}_{3}{ }^{-}$, and organic iodine compounds (R-I) [12]. Disagreement exists between observations of the atmospheric ratio of $\mathrm{I}^{-} / \mathrm{IO}_{3}{ }^{-}$, with one study of tropical Atlantic Ocean air finding a majority of $\mathrm{IO}_{3}{ }^{-}$and negligible $\mathrm{I}^{-}[13]$ and another study finding non-negligible $\mathrm{I}^{-}$concentrations in aerosols [14]. Current models of atmospheric chemistry [3] find that the aerosol $\mathrm{I}^{-}$concentration is negligible due to its transformation into species that revert to the gas phase. However, $\mathrm{IO}_{3}{ }^{-}$is believed to be inert and therefore liable to accumulation with other aerosols [2].

Bromine is a minor constituent in the Earth's atmosphere, but it plays an important role in atmospheric chemistry due to its ozone depletion capabilities [5, 15]. Like iodine, oceans are the main natural reservoir of $\mathrm{Br}$ with average concentrations about $65 \mathrm{mg} \mathrm{L}^{-1}$ [16].

Bromine is released into the atmosphere by sea spray aerosol principally as bromide $\left(\mathrm{Br}^{-}\right)$, as well as by formation of volatile bromocarbons from marine algae [17]. It has been observed that the formation of gas phase bromine results in fresh sea salt aerosol being depleted in $\mathrm{Br}-$ with respect to sea water $[18,19]$.

Inorganic and organic speciation of $\mathrm{I}$ and $\mathrm{Br}$ has been investigated in many environmental matrices including vertical ocean profiles [9], Atlantic coastal waters [20], water macroalgae [21], open ocean deposition [22], and rain [23], as well as snow deposited at the poles [24] and central Europe [5], but no data are available for iodine and bromine species in polar ice. The polar ice caps are important sites for climate studies due to their ability to archive atmospheric constituents, the possibility for accurate sample dating, and their relative distance from anthropogenic pollution sources. Antarctic coastal ice cores additionally offer the possibility to study a wide range of contemporaneous changes in atmospheric and ocean chemistry over several glacialinterglacial cycles [25].

Determination of inorganic $\mathrm{I}$ and $\mathrm{Br}$ species in polar snow and ice is difficult due to the low concentrations present, and for this reason, the focus of our work has been to increase the detection sensitivity after species' separation. Determination of I and $\mathrm{Br}$ species in water has been achieved with many techniques including ion chromatography (IC) [26] and liquid chromatography (LC) [27] coupled with inductively coupled plasma-mass spectrometry (ICPMS), UV detection [28], inductively coupled plasma optical emission spectrometry [29], voltammetric techniques [30], and direct analysis of total concentrations by direct ICP-MS analysis [5]. These techniques feature different detection limits with the lowest being reported for IC-LC-ICP-MS (10 to $40 \mathrm{pg} \mathrm{g}^{-1}$ ) [5] and voltammetric techniques (13 to $\left.25 \mathrm{pg} \mathrm{g}^{-1}\right)$ [30]. Detection limits of UV and polarographic techniques are in the low nanogram-per-gram level [28] which is too high for the determination of $\mathrm{I}$ and $\mathrm{Br}$ species in polar ice.

Volatile brominated hydrocarbon species have been previously detected [31] in Antarctic ice, but no specific focus was made on the presence of inorganic $\mathrm{Br}$. While inorganic $\mathrm{Br}$ in polar ice is likely in the bromide form [5], iodine is mostly present in atmospheric depositions as iodide and iodate; the volatile iodine organic species photo-dissociate rapidly in the atmosphere to generate iodine atoms [32].

Here, we present the first determination of $\mathrm{I}$ and $\mathrm{Br}$ inorganic species in Antarctic ice core samples. The low concentrations of the investigated species have required the development of a sensitive and reliable method for the speciation analysis of I and $\mathrm{Br}$ under ultra-clean conditions at low pictogram-per-gram levels. Using only $0.3 \mathrm{~mL}$ of melted ice, samples have been measured by coupling highperformance liquid chromatography (HPLC), with ion chromatography (IC) and inductively coupled plasma mass spectrometry (ICP-MS). ICP-MS is one of the most powerful techniques for rapid analysis of many elements, with low detection limits and high stability compared with other induced plasma techniques such as ICP-AES [33]. The use of ICP-MS, thanks to its multi-elemental capabilities, has also allowed the simultaneous determination of phosphorus species. The novelty of the method allows the use of aggressive eluents with a standard HPLC pump. Interglacial ice samples were analyzed, with particular attention given to the stability of these species after the ice was melted.

\section{Experimental section}

Working and standard solutions

All reagent solutions and samples were prepared in a shipping container converted into a particle-free laboratory. The laboratory consists of a series of over-pressured working spaces with air qualities ranging from classes 10 to 100 (US Fed. Std 209E, equivalent to ISO 4 to 5) supplied by modular HEPA fan-filter units (Envirco, Sanford NC, USA). 
Ultrapure water (UPW) was produced by a sequence of active carbon and particulate-filtering cartridges (Millipore, Bedford MA, USA) followed by a mixed bed of ion exchange resins (Maxy, La Gardè, France) [34]. The eluent was prepared by dissolving $1.4 \mathrm{~g}$ of $\mathrm{NaOH}(99.99 \%$, SigmaAldrich, Missouri, USA) in $1 \mathrm{~L}$ of UPW producing a $35 \mathrm{mM}$ final solution.

\section{Sample preparation and decontamination}

Samples were collected from an ice core drilled at Talos Dome $\left(159^{\circ} 04^{\prime} 21^{\prime \prime} \mathrm{E}, 72^{\circ} 47^{\prime} 14^{\prime \prime} \mathrm{S} 2315\right.$ masl) in East Antarctica covered by approximately $1,880 \mathrm{~m}$ of ice with an average accumulation rate of $80 \mathrm{~kg} \mathrm{~m}^{-2}$ year $^{-1}$ and a mean annual temperature of $-41{ }^{\circ} \mathrm{C}$ [35]. The samples, dated according to the TALDICE- 1 age scale $[36,37]$, were obtained from a $32 \times 32 \mathrm{~mm}$ square section of the ice core using continuous flow analysis [38]. The ice was melted on a gold-coated brass melt head and distributed to various analytical channels, one of which was used for discrete sampling. For each 1-m-long ice section melted, an integrated sample of $15 \mathrm{~mL}$ was collected. An integrated sample of approximately $15 \mathrm{~mL}$ was collected in a Coulter counter accuvette for each metre of ice melted.

To study the stability and potential matrix effects of inorganic iodine and bromine species in melted ice samples, unmelted pieces of Talos Dome ice were analyzed. The unmelted ice core pieces were cut into $1 \times 1.5 \times 3 \mathrm{~cm}$ pieces using a commercial band saw modified with polyethylene tabletop and guides. The table, guides, and saw were carefully cleaned with acetone and methanol before use. A washing procedure [39] was used to remove any surface contamination from the ice core pieces after they had been cut. Samples were decontaminated by immersion in a sequence of three $20{ }^{\circ} \mathrm{C}$ UPW baths and rinsed with UPW between each immersion step. Samples were immersed in the first bath for 30 to $40 \mathrm{~s}$ resulting in the removal of approximately $50 \%$ of the sample. The second and third baths of 10 to $15 \mathrm{~s}$ removed an additional $20 \%$ from the total sample mass. The final sample mass was thus approximately
Fig. 1 A schematic diagram of the sample introduction system in load and analysis configurations. Valve $V_{l}$ is controls the eluent loading and $V_{2}$, controls sample introduction. Thick lines represent the solution path from the HPLC while thin lines represent paths isolated from the HPLC

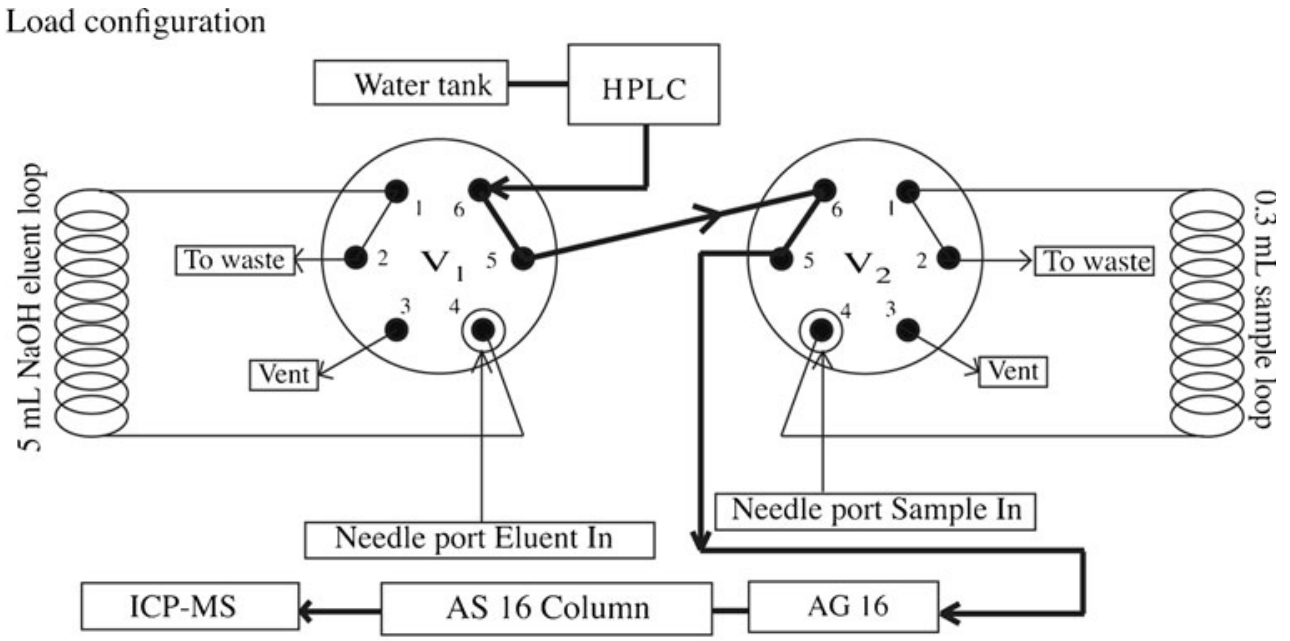

Analysis configuration

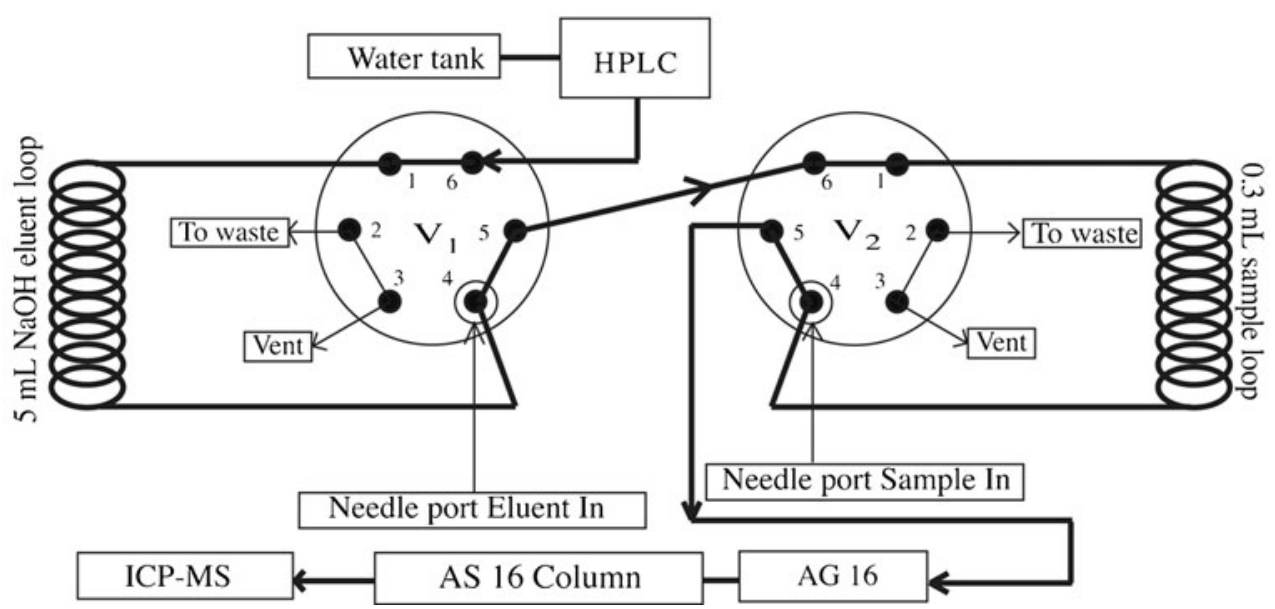


one third of the initial mass. The decontaminated sample was then kept frozen until analysis to prevent any possible modification in I and $\mathrm{Br}$ species.

\section{Apparatus and procedure}

The procedure described here for high-resolution determination of I and Br species by HPLC-IC-ICP-MS is based on a system of two valve-controlled loops (Fig. 1), one which handles the $\mathrm{NaOH}$ eluent (valve $\mathrm{V}_{1}$ ) and the other which handles the sample (valve $\mathrm{V}_{2}$ ). Two loops are necessary to allow the use of a stable and reliable HPLC pump while avoiding any damage to the pump by the basic eluent solution $(\mathrm{NaOH} 35 \mathrm{mM})$ used. The measurement sequence operates as in the following manner: First the eluent was introduced by $\mathrm{V}_{1}$ into a 5-mL loop which guaranteed the volume necessary for a single analysis. Second, the melted ice sample was loaded by $\mathrm{V}_{2}$ into the $0.3-\mathrm{mL}$ loop and injected in the column. Finally, the eluent was flushed through an AG16 guard column and into an AS16 anionic exchange column (Dionex, Milan, Italy). In this way, the columns are able to preconcentrate $\mathrm{Br}$ and I species and then separate them with high resolution [5]. The flux into the introduction system was controlled by a HPLC pump, which used UPW as a carrier. The flow was set to $0.280 \mathrm{~mL}$ per minute with a run time of $9 \mathrm{~min}$ and $70 \mathrm{bar}$ operating pressure. The detector was an Agilent 7500 series ICP-MS (Agilent, CA, USA) with monoisotopic I measured at mass 127 and $\mathrm{Br}$ measured at mass 81 (Instrument parameters in Table 1). The ICP-MS data acquisition began automatically when the sample was injected. This analysis is relatively fast and allows the introduction of a large volume of sample $(0.3 \mathrm{~mL})$ without the loss of analytes (Table 2) while maintaining low detection limits.

\section{Quantifications}

Iodine and bromine species concentrations were quantified by external calibration curves. I and $\mathrm{Br}$ standards were prepared from dilutions of $1,000 \mathrm{mg} \mathrm{L}^{-1}$ stock IC standard solutions (TraceCERT ${ }^{\circledR}$ purity grade, Sigma-Aldrich, MO, USA) in UPW. Iodate $\left(\mathrm{IO}_{3}{ }^{-}\right)$was prepared by the dissolution of $\mathrm{K}^{+}$salts (TraceCERT ${ }^{\circledR}$ purity grade, Sigma-Aldrich, MO, US) in UPW. No memory effects were present between analyses. Chromatographic data analysis software (Agilent, CA, USA) was used for peak integration.

\section{Results and discussion}

Linearity, blanks, and detection limits

Although Antarctic ice can be considered a relatively pure matrix with low elemental concentrations [25], the
Table 1 Instrumental parameters for Agilent 7500 series ICP-MS

possibility of matrix effects was nonetheless investigated. An external calibration was conducted as well as a matched calibration, obtained by melting decontaminated ice. Calibrations spanned the ranges 0.07 to $10 \mathrm{ng} \mathrm{g}^{-1}$ for $\mathrm{Br}^{-}$and $\mathrm{I}^{-}$ and 0.085 to $13 \mathrm{ng} \mathrm{g}^{-1}$ for $\mathrm{IO}_{3}^{-}$. A matrix effect would be identified as a difference in the gradients of the two calibration curves. For $\mathrm{IO}_{3}{ }^{-}$and $\mathrm{Br}^{-}$, no appreciable differences were observed in the gradients but for $\mathrm{I}^{-}$, a matrix effect was present in samples with concentrations greater than $2 \mathrm{ng} \mathrm{g}^{-1}$. For $\mathrm{IO}_{3}^{-}$, the external calibration produced a gradient of $66 \times 10^{4}$ counts $/ \mathrm{pg} \mathrm{g}^{-1}$ while the matched calibrations produced a gradient of $64 \times 10^{4}$ counts $/ \mathrm{pg} \mathrm{g}^{-1}$. For $\mathrm{Br}^{-}$, the external calibration had a value of $11 \times 10^{4}$ counts $/ \mathrm{pg} \mathrm{g}^{-1}$ while the matched calibration had a value of $10 \times 10^{4}$ counts/ $\mathrm{pg} \mathrm{g}^{-1}$. For $\mathrm{I}^{-}$, the external calibration had a gradient of $12 \times$ $10^{5}$ counts/. $\mathrm{pg} \mathrm{g}^{-1}$ while the matched calibration was $10 \times$ $10^{5}$ counts $/ \mathrm{pg} \mathrm{g}^{-1}$. All calibration curves had a correlation coefficient greater than $0.99(\mathrm{df}=3, p=0.05)$. Blank values were obtained by analyzing UPW aliquots according to the same procedure and were used to calculate detection limits. Iodide blank values averaged $3 \pm 2 \mathrm{pg} \mathrm{g}^{-1}$, for $\mathrm{IO}_{3}{ }^{-}$average blank values were $8 \pm 2 \mathrm{pg} \mathrm{g}^{-1}$ while for $\mathrm{Br}^{-}$the average blank value was $4 \pm 3 \mathrm{pg} \mathrm{g}^{-1}$. The detection limits were 
Table 2 Recovery and accuracy of $\mathrm{I}^{-}, \mathrm{IO}_{3}{ }^{-}$, and $\mathrm{Br}^{-}$in an Antarctic ice matrix

\begin{tabular}{|c|c|c|c|c|c|c|c|c|c|}
\hline & \multicolumn{9}{|c|}{ Concentration $\left(\mathrm{pg} \mathrm{g}^{-1}\right)$} \\
\hline & \multicolumn{3}{|l|}{$\mathrm{I}^{-}$} & \multicolumn{3}{|l|}{$\mathrm{IO}_{3}^{-}$} & \multicolumn{3}{|l|}{$\mathrm{Br}^{-}$} \\
\hline & Added & Measured & Recovery $\%$ & Added & Measured & Recovery $\%$ & Added & Measured & Recovery\% \\
\hline Sample & 0 & $29 \pm 1$ & & 0 & 0 & 0 & 0 & $298 \pm 10$ & 0 \\
\hline Addition 1 & 56 & $69 \pm 2$ & 71 & 59 & $65 \pm 5$ & 110 & 50 & $341 \pm 12$ & 86 \\
\hline Addition 2 & 128 & $141 \pm 4$ & 88 & 144 & $130 \pm 6$ & 90 & 123 & $435 \pm 12$ & 111 \\
\hline
\end{tabular}

Fig. 2 Stability of iodine and bromine species in ultrapure water (UPW, open markers) and melted Antarctic ice (MAI, closed markers) shown as their percentage variations with respect to the mean value. The errors for all species were consistently less than $3 \%$. Circles represent $\mathrm{B}^{-}$, squares represent $\mathrm{I}^{-}$, and triangles represent $\mathrm{IO}_{3}{ }^{-}$

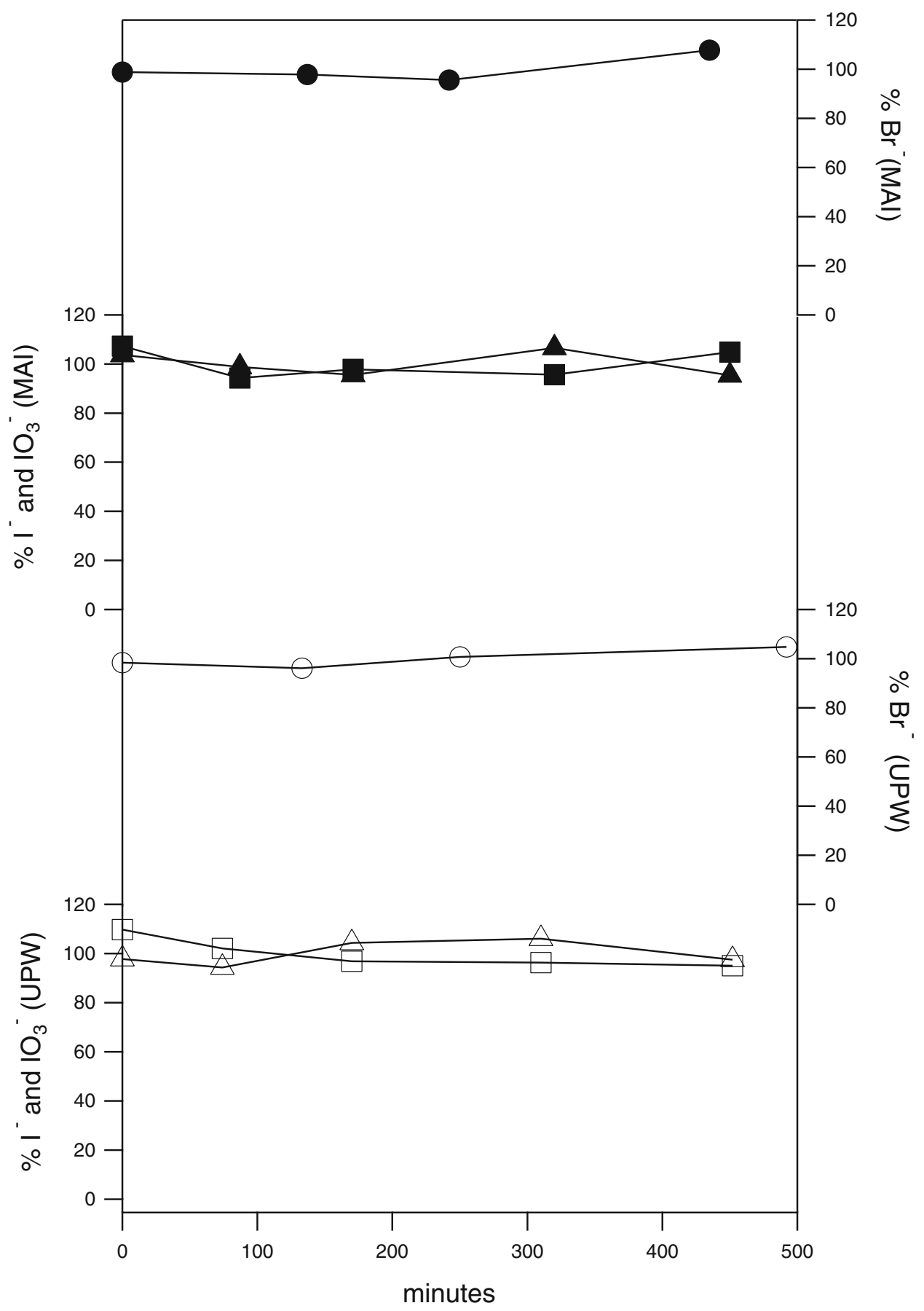


calculated as three times the standard deviation of the blanks and ranged from $5 \mathrm{pg} \mathrm{g}^{-1}$ for $\mathrm{I}^{-}, 7 \mathrm{pg} \mathrm{g}^{-1}$ for $\mathrm{IO}_{3}^{-}$, and 9 for $\mathrm{Br}^{-}$. $\mathrm{BrO}_{3}^{-}$was not detected in the ice samples, despite the detection limit of our technique being $38 \mathrm{pg} \mathrm{g}^{-1}$. Although $\mathrm{IO}_{3}^{-}$was also undetected in the ice samples analyzed here, it has been previously reported in snow deposition [5, 23], and so we have investigated the stability of the species in greater detail.

\section{Recovery, accuracy, and reproducibility}

No certified reference material is available for polar ice matrices, therefore we analyzed melted Antarctic samples spiked with different concentrations of $\mathrm{I}^{-}, \mathrm{IO}_{3}{ }^{-}$, and $\mathrm{Br}-$ in order to evaluate the accuracy and recovery of the studied species. The concentrations of the three species ranged between 50 and $144 \mathrm{pg} \mathrm{g}^{-1}$ (Table 2). Iodide had a weaker retention (71\% recovery) at concentrations of $50 \mathrm{pg} \mathrm{g}^{-1}$ compared with $88 \%$ recovery at $100 \mathrm{pg} \mathrm{g}^{-1}$. $\mathrm{Br}-$ and $\mathrm{IO}_{3}^{-}$ demonstrated a high recovery for all tested concentrations. To ensure reproducibility, and considering previous studies of iodine speciation [23], concentration of $\mathrm{IO}_{3}{ }^{-}$in the matrix-matched standard was fixed to $339 \mathrm{pg} \mathrm{g}^{-1}$. This was required because this species was not found in the interglacial Antarctic ice samples measured. Reproducibility was evaluated by repeating three measurements for each individual sample. All of the determined species demonstrated low residual standard deviations (RSD) of $2.4 \%$ for $\mathrm{I}^{-}$and $\mathrm{Br}^{-}$and $0.91 \%$ for $\mathrm{IO}_{3}^{-}$.

Stability of I and Br species in UPW and melted ice

Despite the purity of the Antarctic ice matrix, there remains a possibility that the trace impurities present in that matrix may alter the species determined here. I and $\mathrm{Br}$ species are highly reactive [40], so the stability of these species in samples of melted Antarctic ice was verified under normal laboratory conditions. Figure 2 shows the concentrations of $\mathrm{I}$ and $\mathrm{Br}$ species determined in a UPW standard over $8 \mathrm{~h}$ : No appreciable variations or trends were observed for $\mathrm{IO}_{3}{ }^{-}$ (open triangles) or $\mathrm{Br}-$ (open circles) over this range of time. $\mathrm{I}^{-}$(open squares) showed a slight decrease during the period of observation which was most likely due to reaction with $\mathrm{O}_{3}$ to produce $\mathrm{I}_{2}$ [13]. To avoid any potential long-term modifications, new I and $\mathrm{Br}$ standards were prepared every 2 days. The same experiment was conducted on a melted ice core sample, this time spiked with $\mathrm{IO}_{3}{ }^{-}$on account of its absence in Antarctic ice. The melted ice was regularly injected and analyzed every $100 \mathrm{~min}$ for $6 \mathrm{~h}$ after melting. Our results (closed markers, Fig. 2) are in agreement with the literature [41] and do not show any appreciable change. This study demonstrates that $\mathrm{I}$ and $\mathrm{Br}$ species are stable in melted ice samples for at least $6 \mathrm{~h}$-much longer than the time required to melt and analyze the Antarctic samples described here.

\section{Ice core samples}

A series of interglacial ice core samples were analyzed covering the age between 8 and $12 \mathrm{Ky}$ before present (BP) (Fig. 3). $\mathrm{I}^{-}$concentrations had a mean value of $11 \mathrm{pg} \mathrm{g}^{-1}$ (maximum $31 \mathrm{pg} \mathrm{g}^{-1}$ ), which was marginally greater than the detection limit of $5 \mathrm{pg} \mathrm{g}^{-1}$. Br- was found to have a mean concentration of $143 \mathrm{pg} \mathrm{g}^{-1}$ and ranged between 92 and $213 \mathrm{pg} \mathrm{g}^{-1}$. Iodate concentrations were always less than the detection limit $\left(7 \mathrm{pg} \mathrm{g}^{-1}\right)$.

These results are consistent with sea salt aerosol being the most important source of $\mathrm{Br}^{-}$in Antarctic snow [42]. As

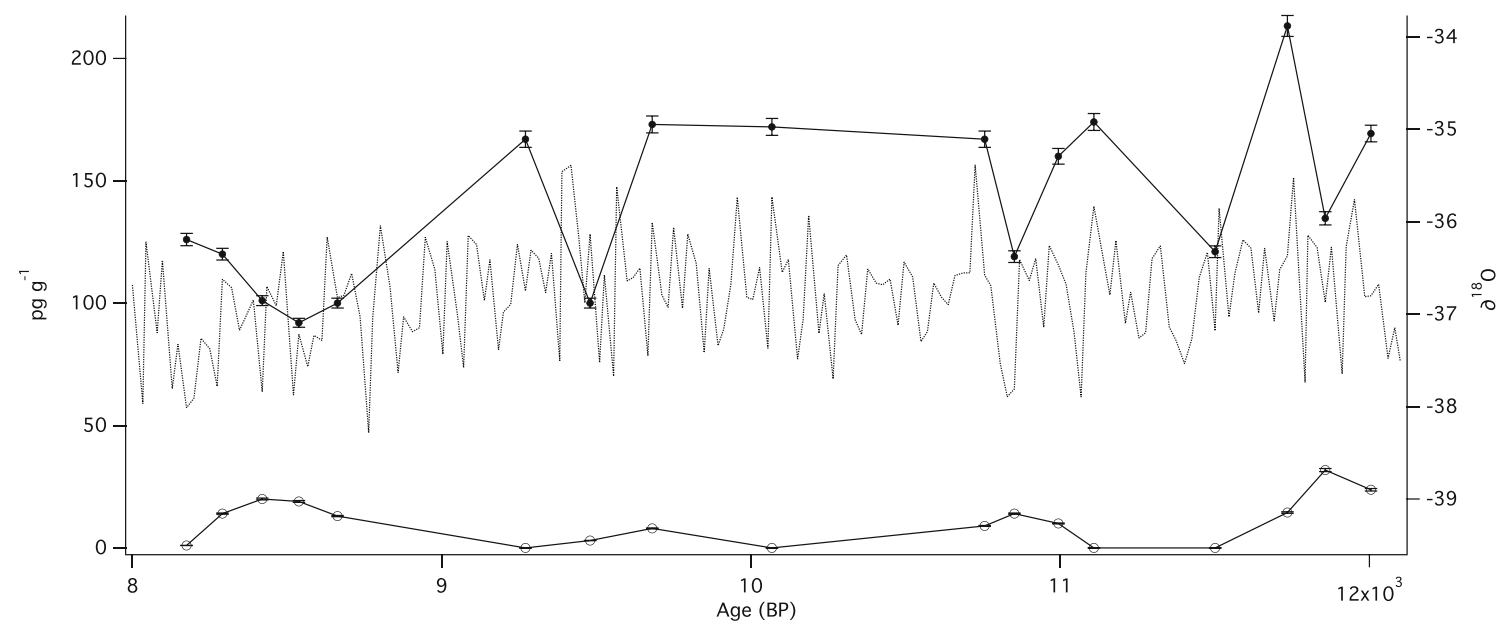

Fig. $3 \mathrm{I}^{-}$concentrations (empty circles) and $\mathrm{Br}^{-}$concentrations (full circles) expressed in pictograms per gram (left axis) in Talos Dome ice core samples, between 8 and 12 thousand years before present (BP).
An isotopic temperature proxy is displayed on the right axis. The measurement uncertainty is smaller than the marker symbol 
would be expected for a period of generally stable climate (the paleotemperature proxy $\delta^{18} \mathrm{O}$ [37] is also shown in Fig. 3), Br- concentrations (Fig. 3, black dots) display little variability.

Iodide concentrations displayed strong variability with occasionally very low values (Fig. 3). Recent studies of marine aerosols [43] and tropical Atlantic Ocean air [22] demonstrated the presence of both iodine oxidation states, $\mathrm{IO}_{3}{ }^{-}$and $\mathrm{I}^{-}$, even though atmospheric chemistry models indicate that atmospheric I should be mainly present in the form of $\mathrm{IO}_{3}{ }^{-}$, due to the transformation of $\mathrm{I}^{-}$into species that revert to the gas phase [44]. Although the ice samples considered in this study originate from a completely different geographic area, our results confirm the findings of Gilfedder et al. [5] who studied I and Br in snowpack. Despite the stability of iodate in particulate and aqueous solutions, only iodide was detected in the ice core samples reported here.

\section{Conclusions}

For the first time, iodine and bromine speciation has been investigated in interglacial Antarctic ice core samples. The proposed method is fast and sensitive, with the ability to reach detection limits in the low picogram-per-gram range ( $5 \mathrm{pg} \mathrm{g}^{-1}$ for $\mathrm{I}-, \mathrm{pg} \mathrm{g}^{-1}$ for $\mathrm{IO}_{3}^{-}$, and $9 \mathrm{pg} \mathrm{g}^{-1}$ for $\mathrm{Br}^{-}$) required to quantify the inorganic bromine and iodine species present in Antarctic ice core samples, with an RSD below 3\% for all species. The analytical approach adopted here could be useful for many HPLC applications where aggressive eluents are required. Particular attention was paid to contamination control: Sample preparation was carried out in a particle-free laboratory (classes 10 to 100), and the samples were decontaminated by sequential washing.

From our results, the iodine and bromine species analyzed are stable in ultra-pure water and in melted Antarctic ice at least for $6 \mathrm{~h}$-sufficient time for analysis. The interglacial ice core results reported here indicate that both I and $\mathrm{Br}$ are present at concentrations in the picogram-per-gram range, but only the inorganic species are present.

Bromide was the only bromine species detected in the analyzed samples and appears not to vary greatly. Iodine was present only in $\mathrm{I}^{-}$form and displayed greater variability. This may indicate changes in marine primary productivity, since the main source of iodine in the atmosphere is the release of organic compounds from the ocean surface. $\mathrm{IO}_{3}{ }^{-}$was not present above detection limits, even though it is believed to be the most stable form of iodine in the atmosphere. Due to the complexity of the atmospheric iodine cycle, further research is necessary to understand the behavior of this species in polar regions. It is also important to investigate the possibility of post-depositional processes which might affect the stability of iodine species in snow and ice.
Acknowledgments This work was supported by the University of Siena and IDPA-CNR. We are grateful to colleagues at the University of Venice for instrumental and technical assistance and in particular to Dr. Warren Cairns of the IDPA-CNR for the discussion on speciation. The Talos Dome Ice Core Project (TALDICE), a joint European program, is funded by contributions from Italy, France, Germany, Switzerland, and the UK. Logistical support was provided by PNRA. This is TALDICE publication no 17.

\section{References}

1. Charlson RJ, Schwartz SE, Hales JM, Cess RD, Coakley JA, Hansen JE, Hofmann DJ (1992) Climate forcing by anthropogenic aerosols. Science 255(5043):423-430

2. Pechtl S, Lovejoy ER, Burkholder JB, von Glasow R (2006) Modeling the possible role of iodine oxides in atmospheric new particle formation. Atmos Chem Phys 6:505-523

3. McFiggans G, Coe H, Burgess R, Allan J, Cubison M, Alfarra MR, Saunders R, Saiz-Lopez A, Plane JMC, Wevill DJ, Carpenter LJ, Rickard AR, Monks PS (2004) Direct evidence for coastal iodine particles from Laminaria macroalgae - linkage to emissions of molecular iodine. Atmos Chem Phys 4:701-713

4. Calvert JG, Lindberg SE (2004) Potential influence of iodinecontaining compounds on the chemistry of the troposphere in the polar spring. I. Ozone depletion. Atmos Environ 38(30):50875104. doi:10.1016/j.atmosenv.2004.05.049

5. Gilfedder BS, Petri M, Biester H (2007) Iodine and bromine speciation in snow and the effect of orographically induced precipitation. Atmos Chem Phys 7(10):2661-2669

6. McFiggans G (2000) A model study of iodine chemistry in the marine boundary layer. J Geophys Res 105:14371-14386

7. Hou X, Hansen V, Aldahan A, Possnert G, Lind O, Lujaniene G (2009) A review on speciation of iodine-129 in the environmental and biological samples. Anal Chim Acta 632(2):181-196

8. Wong GTF (1991) The marine geochemistry of iodine. Rev Aquat Sci 4(1):45-73

9. Tian RC, Nicolas E (1995) Iodine speciation in the northwestern Mediterranean Sea, method and vertical profile. Mar Chem 48 (2):151-156

10. De Luca RA, Herms FW, Wagener K (1990) The cycling of iodine as iodate and iodide in a tropical estuarine system. Mar Chem 29:77-93

11. Luther GW III, Campbell T (1991) Iodine speciation in the water column of the Black Sea. Deep Sea Res A Oceanogr Res Pap 38 (Supplement 2):S875-S882, 0

12. Vogt R, Sander R, Von Glasow R, Crutzen PJ (1999) Iodine chemistry and its role in halogen activation and ozone loss in the marine boundary layer: a model study. J Atmos Chem 32(3):375395

13. Saiz-Lopez A, Plane J (2004) Novel iodine chemistry in the marine boundary layer. Geophys Res Lett 31(4):L04112. doi:10.1029/ 2003GL019215

14. Baker AR (2004) Inorganic iodine speciation in tropical Atlantic aerosol. Geophys Res Lett 31(23):L23S02. doi:10.1029/ 2004g1020144

15. Sander R, Keene WC, Pszenny AAP, Arimoto R, Ayers GP, Baboukas E, Cainey JM, Crutzen PJ, Duce RA, Hoenninger G, Huebert BJ, Maenhaut W, Mihalopoulos N, Turekian VC, Van Dingenen R (2003) Inorganic bromine in the marine boundary layer: a critical review. Atmos Chem Phys 3(5):1301-1336. doi:10.5194/acp-3-1301-2003

16. Greenwood NN, Earnshaw A (2005) Chemistry of the elements. Elsevier, Amsterdam, The Netherlands, 1342

17. Salawitch R (2006) Biogenic bromine. Nature 439(7074):275-277 
18. Simpson WR, Alvarez-Aviles L, Douglas TA, Sturm M, Domine F (2005) Halogens in the coastal snow pack near Barrow, Alaska: evidence for active bromine air-snow chemistry during springtime. Geophys Res Lett 32(4):L04811. doi:10.1029/2004gl021748

19. Ayers GP, Gillett RW, Cainey JM, Dick AL (1999) Chloride and bromide loss from sea-salt particles in Southern Ocean Air. J Atmos Chem 33(3):299-319. doi:10.1023/a:1006120205159

20. Baker J, Reeves C, Nightingale P, Penkett S, Gibb S, Hatton A (1999) Biological production of methyl bromide in the coastal waters of the North Sea and open ocean of the northeast Atlantic. Mar Chem 64(4):267-285

21. Laturnus F, Adams FC, Wiencke C (1998) Methyl halides from Antarctic macroalgae. Geophys Res Lett 25(6):773-776. doi:10.1029/98g100490

22. Baker A, Tunnicliffe C, Jickells T (2001) Iodine speciation and deposition fluxes from the marine atmosphere. J Geophys Res 106 (D22):28743

23. Gilfedder BS, Lai SC, Petri M, Biester H, Hoffmann T (2008) Iodine speciation in rain, snow and aerosols. Atmos Chem Phys 8 (20):6069-6084

24. Simpson WR, von Glasow R, Riedel K, Anderson P, Ariya P, Bottenheim J, Burrows J, Carpenter LJ, Friess U, Goodsite ME, Heard D, Hutterli M, Jacobi HW, Kaleschke L, Neff B, Plane J, Platt U, Richter A, Roscoe H, Sander R, Shepson P, Sodeau J, Steffen A, Wagner T, Wolff E (2007) Halogens and their role in polar boundary-layer ozone depletion. Atmos Chem Phys 7 (16):4375-4418

25. Wolff E, Barbante C, Becagli S, Bigler M, Boutron C, Castellano E, De Angelis M, Federer U, Fischer H, Fundel F (2010) Changes in environment over the last 800,000 years from chemical analysis of the EPICA Dome C ice core. Quat Sci Rev 29(1-2):285-295

26. Gilfedder BS, Petri M, Biester H (2006) Iodine speciation and redox cycling in limnic systems: case studies from Lake Constance and the Mummelsee. Geochim Cosmochim Acta 70(18):A202A202. doi:10.1016/J.Gca.2006.06.408

27. Liu W, Yang H, Li B, Xu S (2011) Determination of bromine and iodine speciation in drinking water using high performance liquid chromatography-inductively coupled plasma mass spectrometry. Geostand Geoanal Res 35(1):69-74

28. Huang Z, Ito K, Timerbaev A, Hirokawa T (2004) Speciation studies by capillary electrophoresis - simultaneous determination of iodide and iodate in seawater. Anal Bioanal Chem 378(7):18361841. doi:10.1007/s00216-004-2506-4

29. Lyon TDB, Robin PA, Watson WS, Littlejohn D (2005) Determination of elevated concentrations of bromine in serum by ICP-MS and ICP-OES. J Anal At Spectrom 20(8):757-759

30. Spokes LJ, Liss PS (1996) Photochemically induced redox reactions in seawater. II. Nitrogen and iodine. Mar Chem 54:1-10

31. Saltzman ES, Aydin M, Tatum C, Williams MB (2008) 2,000-year record of atmospheric methyl bromide from a South Pole ice core. J Geophys Res 113(D5):D05304. doi:10.1029/2007jd008919

32. Saiz-Lopez A, Plane JMC, Baker AR, Carpenter LJ, von Glasow R, Gomez Martin JC, McFiggans G, Saunders RW (2011) Atmospheric chemistry of iodine. Chem Rev. doi:10.1021/cr200029u
33. Slaets S, Laturnus F, Adams FC (1999) Microwave induced plasma atomic emission spectrometry: a suitable detection system for the determination of volatile halocarbons. Fresenius J Anal Chem 364(1):133-140. doi:10.1007/s002160051312

34. Gabrielli P, Varga A, Barbante C, Boutron C, Cozzi G, Gaspari V, Planchon F, Cairns W, Hong S, Ferrari C, Capodaglio G (2004) Determination of Ir and Pt down to the sub-femtogram per gram level in polar ice by ICP-SFMS using preconcentration and a desolvation system. J Anal At Spectrom 19(7):831-837

35. Frezzotti M, Bitelli G, de Michelis P, Deponti A, Forieri A, Gandolfi S, Maggi V, Mancini F, Remy F, Tabacco IE, Urbini S, Vittuari L, Zirizzottl A (2004) Geophysical survey at Talos Dome, East Antarctica: the search for a new deep-drilling site. Ann Glaciol 39(1):423-432. doi:10.3189/172756404781814591

36. Buiron D, Chappellaz J, Stenni B, Frezzotti M, Baumgartner M, Capron E, Landais A, Lemieux-Dudon B, Masson-Delmotte V, Montagnat M, Parrenin F, Schilt A (2010) TALDICE-1 age scale of the Talos Dome deep ice core, East Antarctica. Clim Past Discuss 6:1733-1776

37. Stenni B, Buiron D, Frezzotti M, Albani S, Barbante C, Bard E, Barnola JM, Baroni M, Baumgartner M, Bonazza M, Capron E, Castellano E, Chappellaz J, Delmonte B, Falourd S, Genoni L, Iacumin P, Jouzel J, Kipfstuhl S, Landais A, Lemieux-Dudon B, Maggi V, Masson-Delmotte V, Mazzola C, Minster B, Montagnat M, Mulvaney R, Narcisi B, Oerter H, Parrenin F, Petit JR, Ritz C, Scarchilli C, Schilt A, Schupbach S, Schwander J, Selmo E, Severi M, Stocker TF, Udisti R (2011) Expression of the bipolar see-saw in Antarctic climate records during the last deglaciation. Nat Geosci 4(1):46-49. doi:10.1038/ngeo1026

38. Kaufmann PR, Federer U, Hutterli MA, Bigler M, SchuÃàpbach S, Ruth U, Schmitt J, Stocker TF (2008) An improved continuous flow analysis system for high-resolution field measurements on ice cores. Environ Sci Technol 42(21):8044-8050. doi:10.1021/es8007722

39. Ruth U, Barbante C, Bigler M, Delmonte B, Fischer H, Gabrielli P, Gaspari V, Kaufmann P, Lambert F, Maggi V (2008) Proxies and measurement techniques for mineral dust in Antarctic ice cores. Environ Sci Technol 42(15):5675-5681

40. Vogt R (1999) Iodine compounds in the atmosphere. In: Fabian P, Singh ON (eds) Reactive halogen compounds in the atmosphere. Springer-Verlag, Berlin

41. Yang H, Liu W, Li B, Zhang H, Liu X, Chen D (2007) Speciation analysis for iodine in groundwater using high performance liquid chromatography-inductively coupled plasma-mass spectrometry (HPLC-ICP-MS). Geostand Geoanal Res 31(4):345-351

42. Enami S, Vecitis C, Cheng J, Hoffmann M, Colussi A (2007) Global inorganic source of atmospheric bromine. J Phys Chem A 111(36):8749-8752

43. Chen H, Brandt R, Bandur R, Hoffmann T (2006) Characterization of iodine species in the marine aerosol: to understand their roles in particle formation processes. Front Chem China 1(2):119-129. doi:10.1007/s11458-006-0001-5

44. Saiz-Lopez A, Saunders R, Joseph D, Ashworth S, Plane J (2004) Absolute absorption cross-section and photolysis rate of I-2. Atmos Chem Phys 4:1443-1450 